\title{
Fly Fauna of Livestock's of Marvdasht County of Fars Province in the South of Iran
}

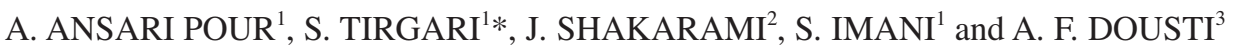 \\ ${ }^{1}$ Department of Entomology, Science and Research Branch, Islamic Azad University, Tehran, Iran \\ ${ }^{2}$ Department of Plant Protection, Faculty of Agriculture, Lorestan University, Lorestan, Iran \\ ${ }^{3}$ Department of Plant Protection, Islamic Azad University, Jahrom Branch, Jahrom, Fars Iran
}

(Received: 5 August 2018; accepted: 13 August 2018)

\begin{abstract}
Flies damage the livestock industry in many ways, including damages, physical disturbances, the transmissions of pathogens and the emergence of problems for livestock like Myiasis. In this research, the fauna of flies of Marvdasht County was investigating, which is one of the central counties of Fars province in southern Iran. In this study, a total of 20 species of flies from 6 families and 15 genera have been identified and reported. The species collected are as follows:

Muscidae: Musca domestica Linnaeus, 1758, Musca autumnalis* De Geer, 1776, Stomoxys calcitrans $^{* *}$ Linnaeus, 1758, Haematobia irritans** Linnaeus, 1758

Fanniidae: Fannia canicularis* Linnaeus, 1761

Calliphoridae: Calliphora vomitoria* Linnaeus, 1758, Chrysomya albiceps* Wiedemann, 1819, Lucilia caesar* Linnaeus, 1758, Lucilia sericata* Meigen, 1826, Lucilia cuprina* Wiedemann, 1830

Sarcophagidae: Sarcophaga africa* Wiedemann, 1824, Sarcophaga aegyptica* Salem, 1935, Wohlfahrtia magnifica** Schiner, 1862

Tabanidae: Tabanus autumnalis* Linnaeus, 1761, Tabanus bromius* Linnaeus, 1758

Syrphidae: Eristalis tenax* Linnaeus, 1758, Syritta pipiens* Linnaeus, 1758, Eupeodes nuba* Wiedemann, 1830, Syrphus vitripennis** Meigen, 1822, Scaeva albomaculata* Macquart, 1842

Species identified with $*$ for the first time in the county and the species marked with $* *$ are reported for the first time from the Fars province.
\end{abstract}

Keywords: Diptera, livestock, Myiasis, Marvdasht, Fars, Iran.

Flies are identified as disturbing species in urban and rural environments and considered one of the most important carriers of disease and death in the worldwide (Taubes, 2000). Many researchers around the world have studied insect species; including Diptera. A list of 835 Palaearctic species of the family Muscidae was published in the catalogue written by Pont in 1986, and 59 of them reported by foreign researchers from Iran (Pont, 1986). In Iran, various researchers have been working on the families, genera and harmful species of order Diptera. Among these families, Calliphoridae and Sarcophagidae are very important because they can transmit the myiasis to animals and humans (Chan et al., 2005; Marinho et al., 2006). 
Taxonomic studies in Iran show that myiasis in humans and livestock is caused by the insects of these two families (Shoorijeh et al., 2009; Namazi et al., 2009; Hall et al., 2009). Both families were surveyed by (Khoobdel et al., 2008) in Iran and a total of 13 species were identified and reported.

The fly fauna of Muscidae and Fanniidae which are the most important insects that carry the pathogens to humans and livestock were studied by Khoobdel and Davari (2011). House fly belonging to the family Muscidae one of the most important insect, which is capable of transmitting pathogens. Other species of this family are not known as insects that contribute to the formation of the myiasis but in some cases, they are introduced as secondary agents in the development of myiasis (Brown et al., 2009). Fanniidae is a small family with 4 genera, and the most important genus of this family is Fannia, This genus is important in terms of medicine and veterinary medicine (Pont, 2002). Insects in this family have been collected and identified in many parts of the world (Rozkošný et al., 1997). Several lists of the flies in this family have been presented in Iran (Tüzün et al., 2010; Khoobdel and Davari, 2011; Dabiri, 2011).

Tabanidae is a large family of Diptera. This family contains blood-feeding insects the hematophagous habit is also very important for livestock economically because a number of pathogens are transmitted by tabanid species (Baldacchino et al., 2014; Maity et al., 2016). Flies of this family are important factors in reducing the milk production of cattle in livestock farms (Datta et al., 1997). Various systematic studies have been done on Tabanidae in Iran and some species have been identified (Abbasian-Lintzen, 1960; Abbasian-Lintzen, 1961; Dousti et al., 2011; Samiei et al., 2016).

The family Syrphidae has more than 6,000 species described throughout the world (Miranda et al., 2013). The insects of this family are important for pollination and predation (Ssymank et al., 2008). Some species of this family such as Eristalis tenax in the larval stage can cause the myiasis (Salimi et al., 2010; Ramezani Awal Riabi et al., 2017).

It is very necessary to identify livestock's fly fauna to control them. For this reason, this research was conducted to control the population of flies in livestock farms. It is known that some fly species in livestock cause myiasis and other livestock diseases; therefore the identification of different fly species in the dairy farm is very important. The failure to identify them and consequently failure to choose the right way to manage the problems caused by flies will reduce the effectiveness of the control.

\section{Material and Methods}

The present research was carried out in Marvdasht dairy farms; Marvdasht County is one of the main counties of Fars province of Iran, the geographical coordinates of the Marvdasht (research area) are $29^{\circ} 52^{\prime} \mathrm{N}, 5^{\circ} 48^{\prime}$ E. Sampling was carried out on 12 dairy farms in different parts of Marvdasht county, the points are as follows:

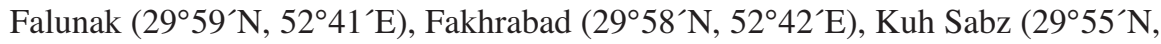
$\left.52^{\circ} 42^{\prime} \mathrm{E}\right)$, Shahrak Khara (30 $\left.00^{\prime} \mathrm{N}, 5^{\circ} 37^{\prime} \mathrm{E}\right)$, Esfadran $\left(29^{\circ} 59^{\prime} \mathrm{N}, 5^{\circ} 44^{\prime} \mathrm{E}\right)$, Majdabad $\left(29^{\circ} 54^{\prime} \mathrm{N}, 52^{\circ} 39^{\prime} \mathrm{E}\right)$, Kamarzard (29 $\left.56^{\prime} \mathrm{N}, 52^{\circ} 38^{\prime} \mathrm{E}\right)$, Dehbid $\left(29^{\circ} 54^{\prime} \mathrm{N}, 5^{\circ} 48^{\prime} \mathrm{E}\right)$, Kenareh $\left(29^{\circ} 54^{\prime} \mathrm{N}, 52^{\circ} 51^{\prime} \mathrm{E}\right)$, Shule Sarooei $\left(30^{\circ} 01^{\prime} \mathrm{N}, 52^{\circ} 50^{\prime} \mathrm{E}\right)$, Fathabad $\left(29^{\circ} 56^{\prime} \mathrm{N}\right.$, $\left.52^{\circ} 48^{\prime} \mathrm{E}\right)$, Shamsabad $\left(29^{\circ} 54^{\prime} \mathrm{N}, 52^{\circ} 54^{\prime} \mathrm{E}\right)$ 
For the better understanding the results, for each location, an upper case letter was considered which include: Falunak (A), Fakhrabad (B), Kuh Sabz (C), Shahrak Khara (D), Esfadran (E), Majdabad (F), Kamarzard (G), Dehbid (H), Kenareh (I), Shule Sarooei (J), Fathabad (K), and Shamsabad (L).

The sampling points are shown in Fig. 1, in this Figure, 12 sampling localities are shown on the map.

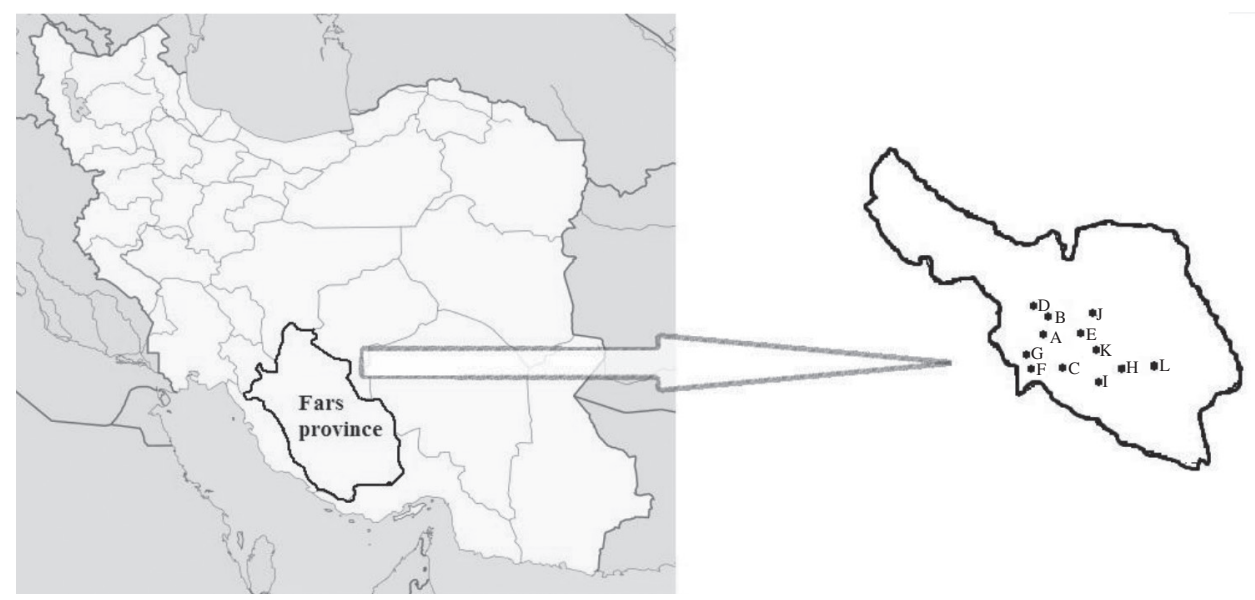

Fig. 1. Sampling locations in Marvdasht dairy farms

Various methods such as insect net, light trap, and sticky trap were used to collect flies inside the dairy farms of Marvdasht County. The method of using the insect net was that in each dairy farm's hall, 20 net sweeps were done, then the trapped insects were killed and stored in alcohol. Light traps were installed at the roof of the cattle halls. Each morning, the traps were examined and samples were collected. The flies were caught inside a glass of cyanide-containing potassium cyanide, and then the specimen specification was done, including the time and place of catch, was attached and transported to the laboratory for diagnosis.

Identification of the specimens was performed using the keys of the families Muscidae, Fanniidae, Calliphoridae, Sarcophagidae, Tabanidae and Syrphidae. For identifying some fly species, it was assisted by various researchers who specialize in identifying the respective family.

For identification of flies, genitalia of the male (aedeagus and other appendages) were used, to make slide from genitalia, cut the end of the male insect's abdomen and they were placed in Petri dishes containing $10 \%$ potassium. After softening and destroying the fatty tissues, the genital system was removed from the potassium solution and washed with distilled water and placed on a slide in a drop of glycerin solution and placed on it. In order to identify the fly species the identification keys by Herting and Dely-Draskovits (1993), Pape (1996), Carvalho (2002), Speight (2010) and Marshall et al. (2011) were used. 


\section{Results}

In this research, a total of 20 species of flies from 6 families and 15 genera were collected. The information about the species collected and their distribution are as follows:

Musca domestica Linnaeus, 1758

The house fly body length $6-8 \mathrm{~mm}$. The highest abundance of insects caught in all dairy farms was related to this species. This species has a global distribution and cosmopolitan, so it has been reported in many parts of Iran.

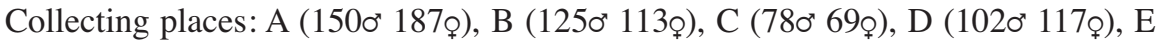

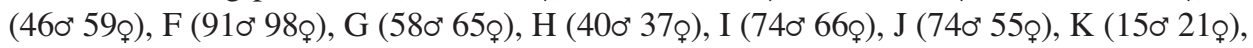
$\mathrm{L}\left(760^{\star 7} 73 \circ\right)$

Distribution: Cosmopolitan

\section{Musca autumnalis De Geer, 1776}

This insect is called face fly. It is similar to the house fly, and its size is slightly larger than the house fly and about 7-8 $\mathrm{mm}$ in length. This species has been reported in Iran from Tehran (Khoobdel and Davari, 2011), Mazandaran (Zielke, 2017), Urmia (Moradi et al., 2013) and Fars (Akbarzadeh et al., 2012).

This species was reported for the first time from Marvdasht County.

Collecting places: A (140"18\%), D (3ơ 1o), J (20"1o)

Distribution: Europe, Russia, China, North Africa, Korea, Japan, Iran (Pickens and Miller, 1980)

Stomoxys calcitrans Linnaeus, 1758

This insect is called stable fly, adults are $6-8 \mathrm{~mm}$ in length, unlike other Muscidae species their mouthparts are piercing-sucking. This insect reduces milk production in cattle dairy farm (Murchie et al., 2018) the presence of this fly in the dairy farm is very important because of the transmission of many pathogens to cows (Baldacchino et al., 2013). This species has been reported in Iran from Tehran (Khoobdel and Davari, 2011), Kashan (Dehghani et al., 2014), Urmia (Moradi et al., 2013).

This species was reported for the first time from Fars province.

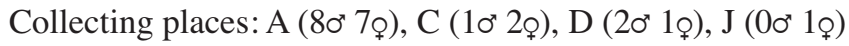

Distribution: USA and Denmark (Birkemoe and Sverdrup-Thygeson, 2011), Brazil (Dominghetti et al., 2015), Northern Ireland (Murchie et al., 2018), Iraq (Hadi and AlAmery, 2012).

\section{Haematobia irritans Linnaeus, 1758}

This insect is called horn fly; adults are $3-5 \mathrm{~mm}$ in length. It is a blood-feeding parasite of cattle. This species has been reported in Iran from Urmia (Moradi et al., 2013).

This species was reported for the first time from Fars province.

Collecting places: A (3ơ 4o), E (20 2o) 
Distribution: Japan (Iwasa and Ishiguro, 2006), Taiwan (Huang et al., 2006), Israel (Müller et al., 2011), Brazil (Barros et al., 2012), USA, Argentina and Mexico (Guglielmone et al., 1998).

\section{Fannia canicularis Linnaeus, 1761}

This insect is called Little House fly or Lesser House fly, the body length of the insect varies from $4.5 \mathrm{~mm}$ to $7 \mathrm{~mm}$. This species has been reported in Iran from Tehran (Khoobdel and Davari, 2011), Urmia (Dabiri, 2011), Shiraz (Habibi et al., 2018)

This species was reported for the first time from Marvdasht County.

Collecting places: A (10 3o), C (10 0o), F (20 4o)

Distribution: China (Wang et al., 2007; Chen et al., 2013), Brazil (Lira et al., 2014), Iraq (Hammodi Hasson, 2016), Palaearctic, Nearctic, Australasian and Oceanian regions (Wang et al., 2007).

\section{Calliphora vomitoria Linnaeus, 1758}

This insect is called Blue bottle fly, the body length of the adult is $10-14 \mathrm{~mm}$. The color of the body is metallic blue with red eyes. This species has been reported in Iran from Tehran (Khoobdel et al., 2008), Urmia (Tüzün et al., 2010), Shiraz (Keshavarzi et al., 2015)

This species was reported for the first time from Marvdasht County.

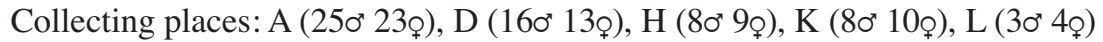

Distribution: Belgium (Frederickx et al., 2011), Czech Republic (Šuláková and Barták, 2013), Iraq (Hammodi Hasson, 2016), Iran, Israel, Pakistan, Saudi Arabia, Syria, Turkey (Akbarzadeh et al., 2015).

\section{Chrysomya albiceps Wiedemann, 1819}

Body length of the insect is 10-14 mm; the larva of this insect causes myiasis. This species has been reported in Iran from Bandar Abbas (Parchami-Araghi, 1995), Greater Tunb, Lesser Tunb and Abu-Musa (Khoobdel et al., 2013), Tehran (Khoobdel and Davari, 2011), Shiraz (Keshavarzi et al., 2015), Kazerun (Parkhideh et al., 2017), Khuzestan (Fakoorziba et al., 2017).

This species was reported for the first time from Marvdasht County.

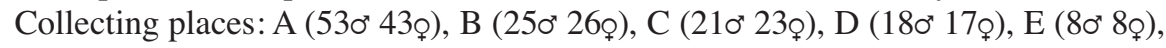

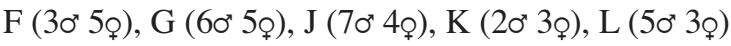

Distribution: Brazil (Pujol-Luz and Barros-Cordeiro, 2012), Italy (Vanin et al., 2009), Egypt, Israel, Iran, Iraq, Kuwait, Lebanon, Libya, Oman, Pakistan, Saudi Arabia, Syria, United Arab Emirates, Turkey (Akbarzadeh et al., 2015), India (Chakraborty et al., 2017), Northwestern India to southern Africa and USA (Wells and Sperling, 1999).

\section{Lucilia caesar Linnaeus, 1758}

The adult body length is $7-11 \mathrm{~mm}$ and the body color is metallic green, legs and antenna are black. This species has been reported in Iran from Tehran (Khoobdel et al., 2008), Shiraz (Keshavarzi et al., 2015) 
This species was reported for the first time from Marvdasht County.

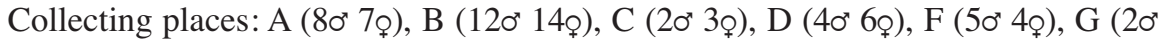

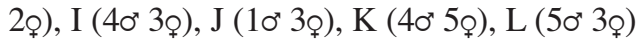

Distribution: Czech Republic (Šuláková and Barták, 2013), Italy (Rognes, 2014), India (Chakraborty et al., 2017), Middle East, Egypt, Iran, Iraq, Israel, Jordan, Lebanon, Libya, Oman, Saudi Arabia, Syria, Turkey, Pakistan (Akbarzadeh et al., 2015).

\section{Lucilia cuprina Wiedemann, 1830}

This insect is called Australian sheep blowfly, the adult body length is 6-9 mm. This species has been reported in Iran from Chaharmahal-Bakhtiary (Pirali-Kheirabadi et al., 2010), Kazerun (Parkhideh et al., 2017)

This species was reported for the first time from Marvdasht County.

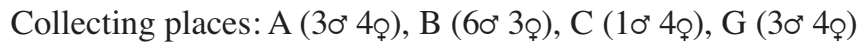

Distribution: India (Bansode et al., 2016), Egypt (Abu Zied et al., 2003), Malaysia (Paul et al., 2009), South Africa (Williams et al., 2014)

Sarcophaga africa Wiedemann, 1830

The adult body length is $7-10 \mathrm{~mm}$, the general color of the body is gray and a few black bars are on the thorax. This species has been reported in Iran from Kermanshah (Salimi et al., 2017), Greater Tunb and Abu-Musa (Khoobdel et al., 2013), Gheshm (Khoobdel et al., 2015), Kazerun (Parkhideh et al., 2017).

This species was reported for the first time from Marvdasht County.

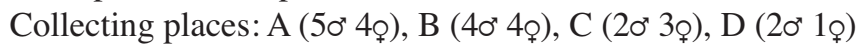

Distribution: South Africa (Villet et al., 2017), Poland (Kaczorowska, 2009), India (Chakraborty et al., 2017)

Sarcophaga aegyptica Salem, 1935

The adult body length is $10-12 \mathrm{~mm}$, the general color of the body is gray and a few black bars are on the thorax. This species has been reported in Iran from Abu-Musa (Khoobdel et al., 2013), Fars (Akbarzadeh et al., 2012), Gheshm (Khoobdel et al., 2015), Kazerun (Parkhideh et al., 2017)

This species was reported for the first time from Marvdasht County.

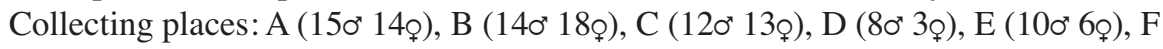

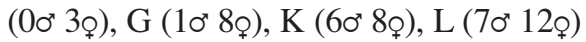

Distribution: South Africa (Villet et al., 2017), China (Ren et al., 2018), India (Nandi, 2002)

\section{Wohlfahrtia magnifica Schiner, 1862}

This insect is called spotted flesh fly; the adult body length is $6-10 \mathrm{~mm}$. Larvae of this species make myiasis in livestock farms. This species has been reported in Iran from Bushehr (Mohammadzadeh et al., 2008), Isfahan (Dehghani et al., 2012), Greater Tunb, Lesser Tunb and Abu-Musa (Khoobdel et al., 2013) 
This species was reported for the first time from Fars province.

Collecting places: A ( $\left.60^{\star} 5 \circ\right), \mathrm{D}\left(70^{\star} 3 \circ\right), \mathrm{G}\left(40^{\star} 2 \circ\right)$

Distribution: Pakistan, Saudi Arabia, countries neighborhood of west sides of the Red Sea, Egypt, Libya, Tunisia, Mauritania, Senegal and Guinea (Spradbery, 2002)

\section{Tabanus autumnalis Linnaeus, 1761}

This insect is called large marsh horsefly; the adult body length is $18-22 \mathrm{~mm}$. This species has been reported in Iran from Fars (Abbassian-Lintzen, 1960), Kerman, Sistan and Baluchestan, Gorgan, Isfahan, Kordestan (Abbassian-Lintzen, 1964), Khorasan (Sadeghi Namghi and Zeegers, 2005)

This species was reported for the first time from Marvdasht County.

Collecting places: C (4ơ 1o), D (3ơ 2o)

Distribution: Iraq, Saudi Arabia, Oman, Jordan, Syria, Kuwait, Turkey, Egypt, Hungary, Italy, Croatia, United Kingdom, USA, Mexico, Brazil, Chile, Colombia (Jasim et al., 2015), Bosnia and Herzegovina (Mikuška et al., 2008)

\section{Tabanus bromius Linnaeus, 1758}

This insect is called band-eyed brown horsefly; the adult body length is $13-16 \mathrm{~mm}$. This species has been reported in Iran from Shiraz (Dousti et al., 2011), Kazerun (Abbassian-Lintzen, 1960)

This species was reported for the first time from Marvdasht County.

Collecting places: K (20 1o)

Distribution: Bosnia and Herzegovina (Mikuška et al., 2008), Turkey (Altunsoy and Kiliç, 2010), India (Maity et al., 2016)

\section{Eristalis tenax Linnaeus, 1758}

This insect is called drone fly; the adult body length is $12-15 \mathrm{~mm}$. This species has been reported in Iran from Arak (Salimi et al., 2010), Khorramabad, Dorud, Poldokhtar (Bahirai et al., 2014), Oromieh, Fars, Ahwaz, Hamadan, Gorgan, Guilan, Marand, Mashhad, Mazandaran, Sistan (Dousti and Hayat, 2006).

This species was reported for the first time from Marvdasht County.

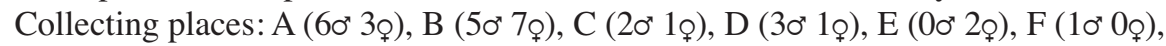
$\mathrm{G}\left(20^{\star} 1 \%\right), \mathrm{K}\left(7 \sigma^{\star} 5 \%\right), \mathrm{L}\left(50^{\star} 4 \%\right)$

Distribution: Spain (Clavel et al., 2011), China (Li et al., 2017), England (Basley et al., 2018), cosmopolitan, the most widely distributed syrphid species in the world, known from all regions except the Antarctic, found throughout Europe except in the far north (Dousti and Hayat, 2006)

\section{Syritta pipiens Linnaeus, 1758}

This insect is called thick-legged hoverfly; the adult body length is $4.5-7 \mathrm{~mm}$. The larvae of these flies in husbandry feed on animal waste. This species has been reported in Iran from Semnan (Samin et al., 2016), Ilam (Bedoreh and Ansari pour, 2012), 
Oromieh, Ahwaz, Gorgan, Guilan, Mashhad, Kashmar and Bardaskan, Khorasan, Kurdistan, Mazandaran (Dousti and Hayat, 2006)

This species was reported for the first time from Marvdasht County.

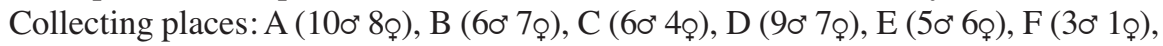
G (4o 4o), K (30*4o)

Distribution: Palaearctic, including North Africa, most of North America, South America and the Oriental region (Samin et al., 2016)

Eupeodes nuba Wiedemann, 1830

The adult body length is $4.5-7 \mathrm{~mm}$; this species has been reported in Iran from Khorasan Razavi (Shojaei Hesari and Pashaei Rad, 2015), Ahwaz (Dousti, 1999), Khorramabad, Fars, Gorgan, Guilan, Mashhad, Kashmar and Bardaskan, Khorasan, Kurdistan, Mazandaran (Dousti and Hayat, 2006), Ilam (Bedoreh and Ansari pour, 2012)

This species was reported for the first time from Marvdasht County.

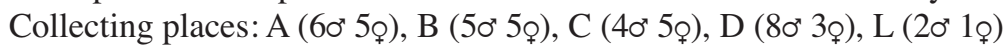

Distribution: China (Jilong et al., 1998), Turkey (Reemer and Smit, 2007), Serbia (Nedeljković et al., 2009), Portugal (Pita et al., 2009), Canary Islands, southern France to Italy, former Yugoslavia, Crete, Cyprus, Lebanon, Israel, Egypt, Morocco, Switzerland, Romania, Uzbekistan, Kirghizia, Afghanistan, Mongolia, Ethiopia (Shojaei Hesari et al., 2016)

\section{Syrphus vitripennis Meigen, 1822}

The adult body length is $8-10 \mathrm{~mm}$; this species has been reported in Iran from Neyshabur (Sadeghi Namaghi and Husseini, 2009), Khorasan (Shojaei Hesari and Pashaei Rad, 2015), East Azerbaijan (Ehteshamnia et al., 2010), West Azerbaijan, Oromieh, Khorasan-e-Razavi, Mashhad, Kashmar and Bardaskan, Golestan province, Gorgan, Mazandaran (Dousti and Hayat, 2006).

This species was reported for the first time from Marvdasht County.

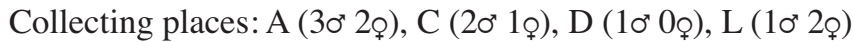

Distribution: Portugal (Pita et al., 2009), Serbia (Nedeljković et al., 2009), Poland (Wojciechowicz-Żytko and Wnuk, 2012), Africa, California, Alaska, Iran (Ehteshamnia et al., 2010)

Scaeva albomaculata Macquart, 1842

The adult body length is $8-10 \mathrm{~mm}$; this species has been reported in Iran from Oromieh, Charmahal and Bakhtiari, Fars, Ahwaz, Gorgan, Mashhad, Brojerd, Karaj, Miandoab, Zabol, Kashmar and Bardaskan, Khorasan, Kurdistan, Shiraz, Kuzestan (Dousti and Hayat, 2006)

This species was reported for the first time from Marvdasht County.

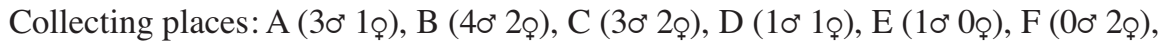

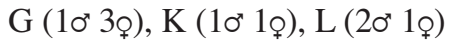

Distribution: Iberian Peninsula and round the Mediterranean basin to Morocco, Canary Islands, eastward through southern Russia, the Caucasus and southern Siberia to the far east and northern China, Afghanistan, Mongolia; highly migratory and occasionally reaches as far north as Britain (Dousti and Hayat, 2006) 


\section{Literature}

Abbasian-Lintzen, R. (1960): Tabanidae (Diptera) of Iran, II. Records of horseflies in the Kazeroon area (province of Fars, southern Iran). description of Silvius shapuricus n. sp. and Tabanus ansarii n. sp. (X1). Acta Med. Iranica 12, 25-37.

Abbasian-Lintzen, R. (1961): Tabanidae (Diptera) of Iran, VII. Additional records of horseflies from Southeast Iran notes on Tabanus canipalpis Bigot. Acta Med. Iranica 4, 12-19.

Abbasian-Lintzen, R. (1964): Tabanidae (Diptera) of Iran. X. List, keys and distribution of species occurring in Iran. An. Parasitol. Humaine Comparée, Paris 39, 285-327.

Abou Zied, E. M., Gabre, R. M. and Chi, H. (2003): Life table of the Australian sheep blow fly Lucilia cuprina (Wiedemann) (Diptera: Calliphoridae). Egypt. J. Zool. 41, 29-45.

Akbarzadeh, K., Rafinejad, J., Nozari, J., Rassi, Y., Sedaghat, M. M. and Hosseini, M. (2012): A modified trap for adult sampling of medically important flies (Insecta: Diptera). J. Arthropod-Borne Dis. 6, 119-128.

Akbarzadeh, K., Wallman, J. F., Sulakova, H. and Szpila, K. (2015): Species identification of Middle Eastern blowflies (Diptera: Calliphoridae) of forensic importance. Parasitol. Res. 114, 1463-1472.

Altunsoy, F. and Kiliç, A. Y. (2010): Karyotype characterization of some Tabanidae (Diptera) species. Türk. Entomol. Derg. 34, 477-494.

Bahirai, F., Mehrvar, A., Gharali, B., Lotfalizadeh, H. A. and Jafari, S. (2014): Diversity of flower flies (Dip.: Syrphidae) in Lorestan province. J. Entomol. Res. 7, 1-15.

Baldacchino, F., Muenworn, V., Desquesnes, M., Desoli, F., Charoenviriyaphap, T. and Duvallet, G. (2013): Transmission of pathogens by Stomoxys flies (Diptera, Muscidae). Parasite 20, 1-13.

Baldacchino, F., Porciani, A., Bernard, C. and Jay-Robert., P. (2014): Spatial and temporal distribution of Tabanidae in the Pyrenees Mountains: the influence of altitude and landscape structure. B. Entomol. Res. 104, $1-11$.

Bansode, S. A., More, V. R. and Zambare, S. P. (2016): Effect of different constant temperature on the life cycle of a fly of forensic importance Lucilia cuprina. Entomol. Ornithol. Herpetol. 5, 1-6.

Barros, A. T. M., Saueressig, T. M., Gomes, A., Koller, W. W., Furlong, J., Santiago Girão, E., Cunha Pinheiro, A., Alves-Branco, F. P. J., Sapper, M. F. M., Braga, R. M. and de Oliveira, A. A. (2012): Susceptibility of the horn fly, Haematobia irritans irritans (Diptera: Muscidae), to insecticides in Brazil. Rev. Bras. Parasitol. Vet. Jaboticabal. 21, 125-132.

Basley, K., Davenport, B., Vogiatzis, K. and Goulson, D. (2018): Effects of chronic exposure to thiamethoxam on larvae of the hoverfly Eristalis tenax (Diptera, Syrphidae). Peer. J. 1-15.

Bedoreh, M. and Ansari pour, A. (2012): Study of syrphid fly in Ilam province and the first report of Merodon hirtus (Hurkmans, 1993) for Iranian fauna. Life Sci. J. 9, 900-904.

Birkemoe, T. and Sverdrup-Thygeson, A. (2011): Stable fly (Stomoxys calcitrans) and house fly (Musca domestica) densities: a comparison of three monitoring methods on pig farms. J. Pest Sci. 84, 273-280.

Brown, B. V., Borkent, A., Cumming, J. M., Wood, D. M., Woodley, N. E. and Zumbado, M. (2009): Manual of Central American Diptera. Vol. 1. NRC Research Press, Ottawa, 728 p.

Carvalho, C. J. B. (2002): Muscidae (Diptera) of the Neotropical Region: Taxonomy. Ed. UFPR., 293 p.

Chakraborty, A., Kumar Saha, G. and Banerjee, D. (2017): Biosystematic checklist of common myiasis causing calliphorids and sarcophagids flies of India. J. Adv. Zool. 38, 199-212.

Chan, J. C., Lee, J. S., Dai, D. L. and Woo, J. (2005): Unusual cases of human myiasis due to old word screwworm fly acquired indoors in Hong Kong. Trans. R. Soc. Trop. Med. Hyg. 99, 914-918.

Chen, Y. O., Zhang, D. and Wang, Q. K. (2013): Alimentary canal of the lesser house fly, Fannia canicularis (Linnaeus) (Diptera: Fanniidae). Entomol. Fennica 24, 35-42.

Clavel, A., Toledo, M., Goñi, P. and Aspiroz, C. (2011): Intestinal myiasis due to Eristalis tenax: report of a new case in Spain. New Microbiol. 34, 335-336.

Dabiri, F. (2011): The parasitoid wasps of synanthropic fly pupae in animal husbandries of Urmia (Iran), investigating their natural parasitism rate and identification of insects that grow up in various body viscera of vertebrates. Ph.D. Thesis, Ankara University, 143 p.

Datta, M., Parui, P. and Mukherjee, M. (1997): Insecta: Diptera. In: Fauna of West Bengal. State Fauna Ser. Zool. Sur. India. Calcutta. 3, 1-76. 
Dehghani, R., Sedaghat, M. M., Esmaeli, N. and Ghasemi, A. (2012): Myiasis among slaughtered animals in Kashan, Iran: descriptive a veterinary entomological problem in the tropics. Iran. J. Veterinary Sci. Tech. 4, 19-28.

Dehghani, R., Takhtfiroozeh, M., Kanani, F. and Aslani, S. (2014): Case report of Stomoxys calcitrans bites in residential area of Kashan, Iran. J. Mazandaran Univ. Med. Sci. 23, 257-261.

Dominghetti, T. F. S., Barros, A. T. M., Soares, C. O. and Cançado, P. H. D. (2015): Stomoxys calcitrans (Diptera: Muscidae) outbreaks: current situation and future outlook with emphasis on Brazil. Braz. J. Vet. Parasitol. 24, 387-395.

Dousti, A. F. (1999): Fauna and diversity of syrphid flies in Ahvaz region. M.Sc. thesis, Shahid Chamran University, $129 \mathrm{p}$.

Dousti, A. F. and Hayat, R. (2006): A catalogue of the Syrphidae (Insecta: Diptera) of Iran. J. Ent. Res. Soc. 8, 5-38.

Dousti, A., Gheibi, M. and Baziar, Z. (2011): Preliminary investigation of the genus Tabanus (Diptera: Tabanidae) in Shiraz region. Plant Prot. J. 3, 85-95.

Ehteshamnia, N., Khaghaninia, S. and Farshbaf Pourabad, R. (2010): Some hoverflies of subfamily Syrphinae of Qurigol fauna in East Azerbayjan province, Iran (Diptera: Syrphidae). Mun. Ent. Zool. 5, 499-505.

Fakoorziba, M. R., Assareh, M., Keshavarzi, D., Soltani, A., Moemenbellah-Fard, M. D. and Zarenezhad, M. (2017): First record of Necrobia rufipes (De Geer, 1775) (Coleoptera: Cleridae) from Khuzestan Province, southwest of Iran, a beetle species of forensic importance. J. Coast. Life Med. 5, 179-181.

Frederickx, Ch., Verheggen, F., Bonnet, S. and Haubruge, E. (2011): Recensement de Calliphora vicina Robineau-Desvoidy, de Calliphora vomitoria L. et de Cynomya mortuorum L. (Diptera: Calliphoridae) dans les collections entomologiques des étudiants de Gembloux Agro-Bio Tech sur la période 1995-2009. Entomol. Faun. Faun. Entomol. 64, 57-62.

Guglielmone, A. A., Kunz, S. E., Volpogni, M. M., Anziani, O. S. and Flores, S. G. (1998): Diagnóstico de poblaciones de la Haematobia irritans (Diptera: Muscidade) resistentes a la cipermetrina en Santa Fe, Argentina. Rev. Med. Vet. 79, 353-356.

Habibi, H., Firouzi, S. and Rohollahzadeh, H. (2018): The flies' as a mechanical vector of avian viral pathogens. International J. Agriculture, Environ. Biores. 3, 221-227.

Hadi, A. M. and Al-Amery, A. M. (2012): Isolation and identification of some blood parasites from midgut of stable fly (Stomoxys calcitrans). AL-Qadisiya J. Vet. Med. Sci. 11, 28-33.

Hall, M. J., Wardhana, A. H., Shahhosseini, G., Adams, Z. J. and Ready, P. D. (2009): Genetic diversity of populations of Old World screw worm fly, Chrysomya bezziana causing traumatic myiasis of livestock in the Gulf region and implications for control by sterile insect technique. Med. Vet. Entomol. 23, 51-58.

Hammodi Hasson, R. (2016): Prevalence of medical and veterinary important Dipterans flies in Diyala province - Iraq. AL-Qadisiyah J. Vet. Med. Sci., 15, 108-114.

Herting, B. and Dely-Draskovits, Á. (1993): Family Tachinidae. In: Á. Soós and L. Papp (eds): Catalogue of Palaearctic Diptera. Anthomyiidae Tachinidae. Hungarian Natural History Museum, Budapest, pp. 118-458.

Huang, Y., Sasaki, H. and Shinonaga, S. (2006): Muscid flies associated with grazing cattle and water buffallos in Taiwan. 6th International Congress of Dipterology, 23-28 September, Fukuoka, Japan, 118 p.

Iwasa, M. and Ishiguro, N. (2006): Genetic survey of Haematobia irritans irritans and H. irritans exigua, and phylogeny of Japanese stomoxyini flies (Diptera, Muscidae). 6th International Congress of Dipterology, 23-28 September, Fukuoka, Japan, p. 125.

Jasim, H. S., Sabr, A. J. and Daoud, A. S. (2015): External morphological study of Tabanus autumnalis L. 1761, (Diptera: Tabanidae) in Iraq. Ibn Al-Haitham J. for Pure and Appl. Sci. 28, 1-6.

Jilong, H., Qingxi, L. and Xingquan, S. (1998): A study of Chinese Eupeodes with descriptions of two new species (Diptera: Syrphidae). Acta Entomol. Sinica 41, 291-299.

Kaczorowska, E. (2009): Flesh flies (Diptera: Sarcophagidae) of sandy and marshy habitats of the Polish Baltic coast. Entomol. Fennica 20, 61-64.

Keshavarzi, D., Fereidooni, M., Assareh, M. and Nasiri, Z. (2015): A checklist of forensic important flies (Insecta: Diptera) associated with indoor rat carrion in Iran. J. Entomol. Zool. Studies 3, 140-142.

Khoobdel, M. and Davari, B. (2011): Fauna and abundance of medically important flies of Muscidae and Fanniidae (Diptera) in Tehran, Iran. Asian Pac. J. Trop. Med. 4, 220-223.

Khoobdel, M., Jonaidi, N. and Seiedi Rashti, M. (2008): Blowfly and flesh fly (Diptera: Cyclorrhapha) fauna in Tehran, Iran. J. Entomol. 5, 185-192. 
Khoobdel, M., Akbarzadeh, K., Jafari, H., Mehrabi Tavana, A., Izadi, M., Mosavi Jazayeri, A., Bahmani, M. M., Salari, M., Akhoond, M., Rahimi, M., Esfahani, A., Nobakht, M. and Rafienejad, J. (2013): Diversity and abundance of medically-important flies in the Iranian Triple Islands; the Greater Tunb, Lesser Tunb and Abu-Musa. Iran. J. Milit. Med. 14, 327-336.

Khoobdel, M., Akbarzadeh, K. and Rafinejad, J. (2015): Fauna and relative frequency of synanthropic flies in the biggest Persian Gulf Island, Qeshm, Iran. Asian Pac. J. Trop. Biomedicine 5, 930-934.

Li, X., Ding, Sh., Li, X., Hou, P., Tang, Ch. and Yang, D. (2017): The complete mitochondrial genome analysis of Eristalis tenax (Diptera, Syrphidae). Mitochondrial DNA Part B, 2, 654-655.

Lira, A. F. A., Tizo-Pedroso, E. and Albuquerque, C. M. R. (2014): Phoresy by Americhernes Aff. Incertus (Pseudoscorpiones: Chernetidae) on a tropical fly Fannia canicularis (Diptera: Fanniidae) in a fragment of the Atlantic Forest, Brazil. Entomological News 124, 24-28.

Maity, A., Naskar, A., Sengupta, J., Hazra, S., Parui, P., Homechaudhuri, S. and Banerjee, D. (2016): An annotated checklist of horseflies (Diptera: Tabanidae) from India with remarks on Surra disease vectors. J. Zool. Studies 3, 50-81.

Marinho, C. R., Barbosa, L. S., Azevedo, A. C., Queiroz, M. M., Valgode, M. A. and Aguiar-Coelho, V. M. (2006): Diversity of Calliphoridae (Diptera) in Brazil's Tinguá biological reserve. Braz. J. Biol. 66, 95100.

Marshall, S. A., Whitworth, T. and Roscoe, L. (2011): Blow flies (Diptera: Calliphoridae) of Eastern Canada with a key to Calliphoridae subfamilies and genera of Eastern North America, and a key to the Eastern Canadian species of Calliphorinae, Luciliinae and Chrysomyiinae. Can. J. Arthropod Ident. 11, 1-93.

Mikuška, A., Krčmar, S and Mikuska, J. (2008): Horseflies (Diptera: Tabanidae) of South-East Herzegovina (Bosnia and Herzegovina). Entomol. Croat. 12, 101-107.

Miranda, G. F. G., Young, A. D., Locke, M. M., Marshall, S. A., Skevington, J. H. and Thompson, F. C. (2013): Key to the genera of Nearctic Syrphidae. Can. J. Arthropod Ident. 23, 1-351.

Mohammadzadeh, T., Hadadzadeh, R., Esfandiari, F. and Sadjjadi, S. M. (2008): A case of gingival myiasis caused by Wohlfahrtia magnifica. Iran. J. Arthropod-Borne Dis. 2, 53-56.

Moradi, S., Tavassoli, M., Naem, S. and Akbarzadeh, K. (2013): Fauna and abundance of veterinary important flies of Muscidae (Diptera) and determination of Thelaziasis vectors in cattle farms of Urmia, Iran. J. Veter. Lab. Res. 5, 29-37.

Murchie, A. K., Hall, C. E., Gordon, A. W. and Clawson, S. (2018): Black border increases Stomoxys calcitrans catch on white sticky traps. Insects 9, 1-7.

Müller, G. C., Hogsette, J. A., Kravchenko, V. D., Revay, E. E. and Schlein, Y. (2011): New records and ecological remarks regarding the tribe Stomoxyini (Diptera: Muscidae) from Israel. J. Vector Ecol. 36, 468-470.

Namazi, M. R. and Fallahzadeh, M. K. (2009): Wound myiasis in a patient with squamous cell carcinoma. Sci. World J. 1, 1192-1193.

Nandi, B. C. (2002): Fauna of India and the adjacent countries Diptera, Vol. X, Sarcophagidae. Published Director, ZSI, Kolkata, 608 p.

Nedeljković, Z., Vujić, A., Šimić, S. and Radenković, S. (2009): The fauna of hoverflies (Diptera: Syrphidae) of Vojvodina province, Serbia. Arch. Biol. Sci., Belgrade. 61, 147-154.

Pape, T. (1996): Catalogue of the Sarcophagidae of the world (Insecta, Diptera). Mem. Intern. Entomol. 8, 1-558.

Parchami-Araghi, M. (1995): The blow-fies of subfamily Chrysomyinae in Iran (Diptera: Calliphoridae). J. Entomol. Soc. Iran. 15, 66-70.

Parkhideh, S. Z., Abai., M. R., Akbarzadeh, K., Rassi, Y. and Rafizadeh, S. (2017): The patterns of succession and evolution on carrion insects during the decomposition of an animal corpse in Kazerun City (Fars Province) during summer and fall - 2015. Ir. J. Forensic Med. 23, 160-173.

Paul, A. G., Ahmad, N. W., Lee, H. L., Ariff, A. M., Saranum, M., Naicker, A. S. and Osman, Z. (2009): Maggot debridement therapy with Lucilia cuprina: a comparison with conventional debridement in diabetic foot ulcers. Int. Wound J. 6, 39-46.

Pickens, L. G., Miller, R. W. (1980): Review article: Biology and control of the face fly, Musca autumnalis (Diptera: Muscidae). J. Medical Entomology, 17, 195-210.

Pirali-Kheirabadi, Kh., Cheraghchi-Bashi, M. and Navidpour, Sh. (2010): Infestation of an owl (Bubo bubo) with Lucilia spp. Comp. Clin. Pathol. 19, 221-224. 
Pita, M. T., Silva, I., Menezes, D. and Gomes, A. (2009): On the syrphid fauna of the Madeira Archipelago and the Salvage Islands, with some first records from Deserta Grande and Selvagem Grande (Diptera: Syrphidae). Boletín Sociedad Entomológica Aragonesa 44, 425-433.

Pont, A. C. (1986): Family Muscidae. In: Á. Soós and L. Papp (eds): Catalogue of Palaearctic Diptera. Scatophagidae Hypodermatidae. Elsevier, Amsterdam, pp. 1-345.

Pont, A. C. (2002): The Fanniidae (Diptera) described by J. W. Zetterstedt. Insect Syst. Evol. 33, $103-112$.

Pujol-Luz, J. R. and Barros-Cordeiro, K. B. (2012): Intra-puparial development of the females of Chrysomya albiceps (Wiedemann) (Diptera, Calliphoridae). Rev. Bras. Entomol. 56, 269-272.

Ramezani Awal Riabi, H., Ramezani Awal Riabi, H and Naghizade, H. (2017): Second report of accidental intestinal myiasis due to Eristalis tenax (Diptera: Syrphidae) in Iran, 2015. Case Reports in Emergency Medicine. 2017, 1-3.

Reemer, M. and Smit, J. T. (2007): Some hoverfly records from Turkey (Diptera, Syrphidae). Volucella, 8, $135-146$.

Ren, L., Shang, Y., Chen, W., Meng, F., Cai, J., Zhu, G., Chen, L., Wang, Y., Deng, J. and Guo, Y. (2018): A brief review of forensically important flesh flies (Diptera: Sarcophagidae). Forensic Sci. Res. 3, 16-26.

Rognes, K. (2014): Grossly inaccurate biodiversity data: an example from Italy regarding blowflies (Insecta, Diptera, Calliphoridae). Boll. Mus. St. Nat. Venezia, 65, 103-120.

Rozkošný, R., Gregor, F. and Pont, A. C. (1997): The European Fanniidae (Diptera). Acta Sci. Nat. Acad. Sci. Bohemicae Brno. 31, 1-80.

Sadeghi Namaghi, H. and Zeegers, T. (2005): Horse flies (Diptera: Tabanidae) from the province of Khorasan (Iran). Dipterological Res. 16, 85-88.

Sadeghi Namaghi, H. and Husseini, M. (2009): The effects of collection methods on species diversity of family Syrphidae (Diptera) in Neyshabur, Iran. J. Agr. Sci. Tech. 11, 521-526.

Salimi, M., Edalat, H., Jourabchi, A. and Oshaghi, M. (2010): First report of human nasal myiasis caused by Eristalis tenax in Iran (Diptera: Syrphidae). Iran. J. Arthropod. Borne. Dis. 4, 77-80.

Salimi, M., Rassi, Y., Oshaghi, M. A., Akbarzadeh, K., Rafizzafeh, S., Chatrabgoun, O. and Falahati, M. H. (2017): 1st International Congress on Vector-Borne Diseases and Climate Change and 3rd Iranian National Congress on Medical Entomology, 3-5 December 2017, Tehran, Iran. 45 p.

Samiei, A., Tavassoli, M and Moradi, S. (2016): First record of Tabanus lunatusfrom Iran. Entomol. Hellenica. 25, 39-41.

Samin, N., Ghahari, H. and Bennewicz, J. (2016): A faunistic survey on the hover flies (Diptera: Syrphidae) of Golestan, Mazandaran and Semnan Provinces, Iran. Acta Phytopathol. et Entomol. Hung. 51, 193-206.

Shojaei Hesari, E. and Pashaei Rad, Sh. (2015): Determination of the fauna of hover flies (Diptera: Syrphidae) in Roshtkhar city (Razavi Khorasan Province). Q. J. Exp. Animal Biol. 4, 17-24.

Shojaei Hesari, E., Pashaei Rad, Sh. and Seifallah-Zade, M. (2016): Hover flies of Khaf city in South-East of Razavi Khorasan Province, Iran. Iranian J. Anim. Biosys. 12, 191-201.

Shoorijeh, S. J., Negahban, S., Tamadon, A. and Behzadi, M. A. (2009): Prevalence and intensity of Oestrus ovis in sheep of Shiraz, Southern Iran. Trop. Anim. Health Prod. 41, 1259-1262.

Speight, M. C. D. (2010): Species accounts of European Syrphidae (Diptera) (2010): In: M. C. Speight, E. Castella, J. P. Sarthou and C. Monteil (eds): Syrph the Net, the Database of European Syrphidae. Syrph. the Net Publication, Dublin, Vol. 59, 285 p.

Spradbery J. P. (2002): A manual for the diagnosis of screw-worm fly. Agriculture, Fisheries and Forestry, Australia. Commonwealth Department of Primary Industries and Energy (AGPS Press), Canberra, Australia, pp. $1-62$.

Ssymank, A., Kearns, C. A., Pape, T. and Thompson, F. C. (2008): Pollinating flies (Diptera): A major contribution to plant diversity and agricultural production. Biodivers. 9, 86-89.

Šuláková, H. and Barták, M. (2013): Forensically important Calliphoridae (Diptera) associated with animal and human decomposition in the Czech Republic: preliminary results. Čas. Slez. Muz. Opava (A). 62, $255-266$.

Taubes, G. (2000): Searching for a parasite's weak spot. Science 290, 434-437.

Tüzün, A., Dabiri, F. and Yüksel, S. (2010): Preliminary study and identification of insects' species of forensic importance in Urmia, Iran. African J. Biotech. 9, 3649-3658. 
Vanin, S., Caenazzo, L., Arseni, A., Cecchetto, G., Cattaneo, C. and Turchetto, M. (2009): Records of Chrysomya albiceps in Northern Italy: an ecological and forensic perspective. Mem. Inst. Oswaldo Cruz, Rio de Janeiro, 104, 555-557.

Villet, M. H., Clitheroe, C. and Williams, K. A. (2017): The temporal occurrence of flesh flies (Diptera, Sarcophagidae) at carrion-baited traps in Grahamstown, South Africa. African Invert. 58, 1-8.

Wang, M. F., Wang, R. R. and Xue, W. Q. (2007): A review of the lucidula-subgroup of the Fannia canicularis species-group (Diptera: Fanniidae). Zool. Studies 46, 129-134.

Wells, J. D. and Sperling, F. H. (1999): Molecular phylogeny of Chrysomya albiceps and C. rufifacies (Diptera: Calliphoridae). J. Med. Entomol. 36, 222-226.

Williams, K. A., Richards, C. S. and Villet, M. H. (2014): Predicting the geographic distribution of Lucilia sericata and Lucilia cuprina (Diptera: Calliphoridae) in South Africa. African Invert. 55, 157-170.

Wojciechowicz-Żytko, E. and Wnuk, A. (2012): The occurrence of Syrphidae in Aphis fabae Scop. (Hemiptera) colonies on broad bean intercropped with Phacelia (Part II). J. Plant Protec. Res. 52, 196-201.

Zielke, E. (2017): Some new records of the muscid fauna from Iran, with the description of Helina irani spec. nov (Diptera: Muscidae). J. Entomol. Zool. Studies 5, 442-446. 
